\title{
The Campaign of Papua Peace Network for Papua Peace Land
}

\author{
Cahyo Pamungkas
}

\begin{abstract}
This article aims to narrate a series of peaceful campaigns conducted by Papua Peace Network (PPN) for Papua Peace Land. This informal network consists of several groups of civil societies, such as religious organizations, ethnic groups, NGOs, and academicians. The PPN has some objectives that are to connect conflicted groups in Papua land, and to help both Papuan people and Indonesian government preparing an inclusive dialogue. This article results from research between 2013 and 2017. The data collection used observation of peaceful campaign of PPN, interviews, and archival research. This research shows that although a series of peaceful campaigns have been conducted by PPN both at the national and local levels between 2013 and 2016, but political violence still increases in Papua land. On another side, the national government only focuses on social and economic development issues, in particular, infrastructure projects, instead of political issues. Government officials involved in peaceful campaigns conducted by PPN had no power enough to implement some peace recommendations due to the national government has no a roadmap to resolve the conflict between Jakarta and Papua peacefully. The article argues that a continuously informal communication between conflicted parties is a necessary condition, but it is not a sufficient condition to create a positive peace. Therefore, the National Government is strongly suggested to implement an inclusive national dialogue with Papuan people.
\end{abstract}

\section{Keywords:}

Papua peace network; Papua peace land; reconciliation; dialogue.

\section{Introduction}

The relationship between Papuans and the Indonesian government consistently has been in trouble since the integration of this region into the Indonesian state in 1963, based on the 1962 New York Agreement between Indonesia and the Netherlands. The conflict between Papua and Indonesia became more violent in the 1970s when the Free Papua Organization proclaimed the

\footnotetext{
- Indonesian Institute of Sciences (LIPI). Email: cahyopamungkas_lipi@yahoo.com.
}

revolutionary government of West Papua. ${ }^{2}$ Then, a series of political violence conducted by Indonesian military is ongoing until the present day although the level of intensity is lower after the 1998 political reform. Political violence in West Papua is the longest separatist conflict in Indonesia's history compared to the Aceh conflict (1976-2005) and East Timor (1975-1999) (Heidbuchel, 2007: 157; Bhakti, Yanuarti \& Nurhasim, 2009: 17-18; Wassel, 2014: 2-5). Other problems in these regions are depopulation of Papua natives since the

\footnotetext{
2 In this article, the term of Papua and West Papua is exchangeable. Papua geographically refers to Papua land consisted of the present Papua and West Papua provinces, West Papua is a political term used by the people of Papua to express their political identity.
} 
1970s and marginalization of Papua natives in socio-economic development. Although West Papua is incredibly rich in natural resources, this region is the poorest province in Indonesia. These unsolved problems increase distrust between the Indonesian government and the Papuans.

Some studies have been conducted to analyze conflict in West Papua. One of the most quoted studies is the research by Widjojo et al. (2008: 1-4) on Papua Road Map. They identify four root problems of the Papuan conflict, namely: different standpoint of the Papuans and the Indonesian government concerning the history of Papua integration, human rights abuse, and political violence, unsuccessful developments in Papua, and marginalization of Papuan. These findings are discussed widely in other studies conducted, such as ICG (2010; 2012), King, Elmslie \& Webb-Gannon (2011), Barber \& Moiwend (2011), Macleod (2011), Drooglever (2010) and Anderson (2015). Nevertheless, both Papua Road Map and those studies have no focus on peaceful efforts and transformation. Those studies analyze the root of Papuan conflict by using structural approach and power relation. This study tries to fill a gap on the lack of peace studies on West Papua issues. Different from those studies, this article highlights on peaceful efforts conducted by Papua Peace Network (PPN, Jaringan Damai Papua or JDP) that mediate dialogue between the national government and Papuan leaders. Therefore, this article aims to describe PPN's efforts to promote a peaceful dialogue between Papuan people and the national government of Indonesia.

My research argues that an inclusive dialogue is necessary to eliminate the gap of understanding between the national government and Papuan people. Such dialogue is an approach to transform Papuan conflict from violence into peaceful negotiation. The perspective differences between Papua and Jakarta in understanding the root of the Papuan conflicts creates a significant distrust between both parties, thus making empathy difficult to breed. The lack of empathy complicates the implementations of permanent rule and regulations to implement peace in Papua land. Dialogue is a mechanism involving all conflicting parties to identify the problem and find a peaceable solution together. The real dimension of efforts in resolving Papuan conflict-related issues exists in the community, including traditional conflict resolution mechanisms representing some characteristics of Papuan culture (Elisabeth et al., 2005).

\section{Literature Review}

Indonesian sovereignty in West Papua is not yet consolidated because there are still strong resistances to the Indonesian government. Although the national government has implemented many peace policies, such as granting special autonomy in 2001, and ended officially military operation since the 1998 political reform, political violence committed by the Indonesian military not yet stop (Lundry, 2009: 245; Viartasiwi, 2014: 293). Referring to Galtung, Braithwaite et al.'s (2009) said that no positive peace in West Papua since integration into Indonesia in 1963. Positive peace means 'commitment to peace and commitment to the legitimacy of the governance arrangements for guaranteeing peace and justice.' According to Galtung (1969: 183), negative peace can be seen as the absence of organized physical violence, while positive peace can be perceived as the absence of structural or the existence of justice. Rutherford (2012) in the laughing of Leviathan analyzes the asymmetric power relations between Jakarta and Papua as an obstacle to peace building. The other study on Papua, Kirksey $(2012,90)$ mentions that Papua activists are entangled in the Indonesian reform movement, government security forces, and global market. He suggests the need for collaboration instead of resistance because collaboration is an alternative for survival 
to influence the international world. However, both Rutherford and Kirksey do not offer a road map to peace building.

There are several analysis on the sources of Papuan conflict, i.e., the political construction of Papua identity and political violence conducted by the Indonesian military. Chauvel (2005) explains that Papuans feel intense hatred because they are seen as mere objects in decolonizations without a chance to be a participant, or in other words, having a decolonization without the colonized. According to Chauvel, the principle of self-determination that is underhandedly done in the 1969 act of free choice becomes the centerpiece of the Papuan nationalism. There is consistency in the discourse that Papuans have continuously tried to establish a liberated country, which started by the political manifestation on 1961 and continued at the international lobby process by Nicholas Jouwe on the 1970s until the 1999 petition for independence by Tom Beanal.

McGibbon (2006) argues that the growth of Papuan nationalism is influenced by the Dutch governments' promise to give independence to Papua. However, due to the Dutch's weak power, they refuse to continue any further talks regarding Papua's independence. According to McGibbon, although Papuan elites have failed in declaring Papua's independence, the promise was a fundamental point that pushes contemporary Papuan nationalists to strive for freedom. The acceptance of the 1969 plebiscite results by the United Nations shows how the conflict resolution models regarding Papua's political situation is done through a cold war, meaning that the results were made without the consent of the Papuan elites.

Apart from Chauvel and McGibbons, Thorning and Kivimaki (2002) also embrace the basic Papuan conflict. According to them, the conflict is based on the construction of "Papua" created by Indonesian nationalists as a colonial discourse to legitimate the presence of Indonesians in Papua. The stereotype planted by Indonesian nationalists shows a tendency to underestimate Papuans. Based on LIPI research (2004), the central problem of Papuan conflict lies in the perceptual difference about the construction of nationalism among Papuans and other Indonesians. Thorning and Kivimaki argue that regarding the political rights of Papuans as citizens of Indonesia, their cultural, economic and educational difference differs them from other Indonesians in a vast political discourse.

Based a study conducted by LIPI (2008), as an implication of the military-defined Indonesian nationalism construction, the efforts to maintain the unification of Indonesia is adjacent to the war against potential enemies. For the military-dominated Indonesian nationalists, the unified form of Indonesia is a must. Thus, the idea of separating oneself from Indonesia is viewed as a violation of the law. The concept of Negara Kesatuan Republik Indonesia (Unitary State of the Republic of Indonesia, "NKRI" for short) is a hegemonic official text on verified nationalism that legitimized by military forces. The living example of this text occurred during New Order that military forces thoroughly represented Indonesia as the state. In the Papuan conflict, protests conducted by the Papuans against the state policies which exclude the participation of Papuans was regarded as an act of separatism, like separatist movements under the Organisasi Papua Merdeka (Free Papua Organization, "OPM" for short).

The presence of Indonesian government during the year 1962 in Papua marks a beginning of political violence. During 1962 and 1984 precisely, a "secret war" between the Tentara Nasional Indonesia (Indonesian National Army, "TNI" for short) with the OPM occurred. Political violence was not a mere concept, but a real-life experience felt by Papuans as a result of the strategy displayed by the Indonesian government to battle OPM. Indonesian representatives in Papua were mostly military and police officers. Indonesia, 
as an institution, exists in Papua as a military force.

In the context of the Indonesian political state during the New Order, political violence was justified as a "holy job" done by the TNI to maintain NKRI's unification. Although the New Order regime ended on 1998, political violence still continues, even until now. After the fall of the New Order, there has been some changes of political violence: (i) the military operations deployed to end separatism faced questions by NGOs and the church, directly creating a negative persona of the TNI, (ii) political struggles for Papua's independence took over by Papuan intellectuals and representatives of the church. However, (iii) the experience of having endured political violence does not make the Indonesian government, let alone the TNI, change their strategy in dealing with separatism. Troops are repeatedly deployed to prevent separatism from happening. As a result, political violence does not decrease one bit, even after the Reforms (an era emerging after the New Order).

The Indonesian government established Act No. 21/2001 about Otonomi Khusus Papua (Special Autonomy of Papua) that expanded to Act No. 25/2008, to put Papuan conflict end. However, some government elites misunderstand the meaning of special autonomy, they stated that the transfer of money would resolve all problems in Papua (Santoso, 2012: 2-3). In line with the special autonomy, the national government implements the division of Papua province and several regencies. Developing new regencies/cities has directly created an increase of physical infrastructure projects and a flow of funds transfer from Jakarta to Papua. It is estimated that the number exceeds IDR 67 trillion since 2002) consisted of special autonomy and infrastructure fund ("Penyeleseian Papua" 10 November 2017). According to Suryawan (2011: 141), special autonomy and division of local government only bring Papuan elites more divided and fragmented because of political contest. These occur due to no significant economic and social development in Papua that benefitted from Papuan. Therefore, Papuan elites exploited division of local government for merely their self-interest.

The special autonomy is not yet successful in resolving the Papuan conflict. As prove, political violence and tensions between the government and some groups of Papuan people intensified. In addition, the ideas of independent Papua strengthened amidst of youth generations such as the establishment of Komite Nasional Papua Barat (National Committee of West Papua, KNPB) (Wilson, 2016). The failure of special autonomy indicates that there is still a gap in understanding Papuan conflict between the National Government and Papuan people (Elisabeth et al., 2015). The government always emphasizes that the root of Papuan conflict is the lack of economic development. However, the Papuan often says the main problem is not only economic development but also the politics of identity and human right abuses against Papuan people. Therefore, to reduce the gap, it is necessary to implement a dialogical approach that ensures both sides shall end the political violence and bring their problems to the table.

\section{Public Consultations in Papua Land}

Before 2014, the term 'dialogue' is difficult to be accepted by either national government officials or Papuan activist. The government tends to stigmatize dialogue as an act of separatism. Papuan activist says that dialogue is an effort of pacification. Just few peace activist or institutions work for dialogue between Jakarta and Papua. The campaign for dialogue between Jakarta and Papuan people has been initiated by a set of peace activists in both Jakarta and Papua in 2008. At the end of that year, LIPI introduced Papua Road Map, which involves the dialogue between Jakarta 
and Papua. After the publication, the urgency of the dialogue was presented through a series of dissemination to the national government, parliament, NGOs, religious institutions and a list of international communities abroad.

In 2009, LIPI and Sekretariat Keadilan dan Perdamaian (SKP, Office for Justice and Peace, Catholic Church Diocese of Jayapura) initiated a network of dialogue's facilitators. The SKP hosted a conference in 2010, which concluded some indicators of Papua peace land. After that, LIPI trained dialogue's facilitators in seven adat (customary) territories. Former participants then established the Peace Papua Network (PPN) that works voluntarily to promote dialogue, as well as facilitating the preliminary consolidation towards dialogues between the national government and the people of Papua.

PPN was established in 2010 to facilitate dialogue between the Indonesian government and the Papuans and to stimulate communication between Papuans to conclude the Papuan conflict. This network was established by the coordinator of Papua research team of LIPI, who is also an editor of Papua Road Map (Supriyono, 2014: 66), Muridan S. Widjojo, with a Catholic priest, the Director of Sekolah Tinggi Filsafat dan Teologi (Institute of Philosophy and Theology, "STFT" for short) Fajar Timur Jayapura, Pater Neles Tebay. Pater Neles Tebay is also an author of the book Dialog Jakarta-Papua (SKP 2009) that received a warm welcome by Papuan people. A series of discussions emerged to discuss the possibility of future Jakarta-Papua dialogues. Pater Neles was present in debates and discussions about the dialogue with not only intellectuals but also activists from various groups. The idea of dialogue spread quickly and received different responses. Many moderate groups either Papuan or migrant ethnicities supported the idea of dialogue to resolve the conflict. However, conservative groups both in Papua and Jakarta rejected dialogue because of threatening the Indonesian state.

As an organization, PPN is a network of voluntary peace facilitators coming from diverse cultural, religious, and educational backgrounds. Their invidual participations in the PPN do not represent the opinion of any home institutions. The only thing bonding them to PPN is their commitment to work for peace in Papua (Widjojo \& Tebay 2010). Trained facilitators from various civil societies, from lecturers to researchers, from higher education students to social institutions, from religious organizations to ethnic organizations and different strategic groups were gathered to be willing members of the PPN. Their primary task is to connect different groups and help Papuans and Indonesians in general to establish a Jakarta-Papua dialogue. Right now, there are 30 facilitators represent various institutions from both Papua and non-Papua, which around $30 \%$ of the members are women. Above that, PPN also has regional coordinators in different cities from which they have held several public consultations. ${ }^{3}$ The members of PPN work for "Papua Tanah Damai" (Papua Peace Land) via dialogue.

The primary task of PPN members is to facilitate the process of perceptual synchronization about Papua peace land between ethno-religious groups lives in Papua. After the establishment of PPN in 2010, it has actively promoted the concept through a series of public consultations, both inside and outside Papua. The PPN has succeeded in holding public consultations in 19 regencies in Papua. The consultations also involved representatives of migrants in six regencies. In every public consultation, the public was given an understanding of the concept of dialogue and was asked to give their opinions and hopes for future dialogues.

PPN also held seminars for higher education students, academicians, and women to engage with Papuans thoroughly. The

3 Website JDP, http://jdp-dialog.org/profil/tentang-jdp, accessed on March 14, 2016. 
Catholic Church in Papua took the initiative to break down the indicators of Papua Tanah Damai through a workshop. The indicators were discussed and enriched through the workshop in Jayapura in June 2011. The workshop brought all PPN members, researchers, and experts in related fields and representatives from various religious organizations in Jayapura. Following the series of public consultations and workshops, the Papua Peace Conference was successfully held in July 2011. All participants agreed with the declaration that dialogue is the best way to conclude the Papua conflict."

Papua Peace Conference was hosted by the PPN in Jayapura. The event was attended by representatives of the region, the Central Government, Papuan delegations, and local academicians. Among these are Coordinating Minister of Politics and Security, Governor of Papua, Police Chief, Military Commander, Bishop of Diocese Jayapura, Papua Muslim Assembly, Synods of Papuan Churches, and Papuan Adat Council. ${ }^{4}$ The conference participants were selected through some public consultations held by the PPN. Participants of the conference represent the aspirations of the mainstream of indigenous Papuans. It is indicated by the presence of traditional leaders, religious, the Papuan Presidium Council, which is known critical of government policies. The result of the conference is Papua Land of Peace Indicators in politics, security, law and human rights, social, cultural, economic and environmental. The conference chooses negotiators representing Papua native to dialogue with the Government of Indonesia. They are Papuan diaspora, i.e. Rumakiek Rex, John Ondawame, Leoni Tanggahma, Octo Motte and Benny Wenda. They live in Australia, Vanuatu, the Netherlands, USA, and the UK. ${ }^{5}$

\footnotetext{
$4{ }^{*}$ jdp, http://www.jdp-dialog.org/download/ cat_view/17-pers-release-jaringan-damaipapua?orderby $=$ dmdate_published\&ascdesc $=$ DESC, accessed on March 13, 2016.

5 Retrieved from http://tabloidjubi.com/2014/10/11/
}

Reading the declaration of the Papua Peace Conference that contains the name of those five negotiators finally raised critical responses from some participants, the Indonesian Government, and Foreign Affairs. Some the national government officials were struck by reading the name, and since then, the government's trust to PPN and some dialogue campaigns were reduced. This incident is an unplanned; suddenly emerge spontaneously from the conference participants so that the committee cannot be prevented because the pressure of the members was very enthusiastic. Of it was, and then trust the government to the PPN, and the work of the dialogue began to wane. However, based on experience during the decades in which the opinions of Papua always silenced, so they are always trying to express their views on every occasion.

One of government responds against the 2011 Papua Peace Conference as well as international accusation for human right abuse is establishing the so-called UP4B (Unit Percepatan Pembangunan Provinsi Papua dan Papua Barat, the Presidential Office for Speed Development in Papua) at the end of 2011 (Hernawan, 2013). This institution aims to strengthen the coordination of the Papua development acceleration. However, the UP4B only focuses on quick win programs in the educational, health, local economy, and infrastructure development sectors. According to the majority of Papuans, UP4B has yet involved Papuans, especially in security and law enforcement issues. They also state that UP4B has not provided any protection towards the social, economic, and cultural rights of the native Papuans. In their perception, security policies and freedom of expression displayed by the government still uses repressive approaches. Much political violence still exists committed by Indonesian armed forces, pro-

orang-papua-harus-bicara-pengganti-juru-rundingpapua-ondawame/, accessed January 20, 2016. 
independent movements, and other armed civilian groups.

\section{Explorative Meetings between National Government and Papuan Leaders}

Constructive communication is a key to reduce the gap of understanding between national government officials and Papuan people. In 2012, the Office of Vice President initiated an explorative meeting between Papuan leaders and the national government officials. Following the initiatives of Vice President Office; LIPI and PPN held a series of explorative meetings to facilitate such a constructive communication between government and Papuan leaders. The meetings took place six times in seven different cities, namely: Denpasar, Manado, Lombok, Yogyakarta, Semarang, Jakarta, and Bogor. Non-Government Organizations, Civil societies elements, national and local government attended those meetings. The explorative meetings aim to build effective communication and identify the root of the Jakarta-Papua conflict. The meetings were necessary to bridge the gap of understanding between the Indonesian government and Papuans.

Since 2013, LIPI and PPN facilitated explorative meetings that bring together leaders from Papua and Jakarta, as follows (Wiratri, 2016: 19-25). The meeting between the two sides started with First Explorative meeting held in Bali in February 2013. Representatives of ministries and agencies in Jakarta (26 delegations), as well as representatives, attended the meeting from Papua. This explorative meeting discussed issues that can help the parties to create a shared vision that is acceptable to all stakeholders for the future of Papua and to build mutual trust between participants representing various stakeholders from Jakarta and Papua. The first explorative meeting went very tense. Each representative from both ministries and agencies of Jakarta and Papuan activists were still suspicious of each other. Nevertheless, this session is an excellent opportunity to bring the two warring factions. At the end of the meeting, all participants agreed to meet again in the next explorative meeting

The second explorative meeting was held in Manado in April 2013. As previously explorative meetings, this meeting also aims to build confidence and understanding of the problems in Papua, as well as the search for a solution acceptable to all parties. Discussions on this second explorative meeting specifically focused on three aspects: the sociocultural, economic, political, and security laws. In this session, the government has committed to provide a solution to the problem of political conflicts, security, socio-economic and other development aspects, although the government also has obstacles in the coordination and implementation of the program. The Government also emphasized that they will discuss with various interest groups in Papua, including Organisasi Papua Merdeka (OPM).

In August 2013, an explorative meeting was held back in Lombok. At this third meeting, participants were divided into three different groups, namely politic, economic, and sociocultural following the educational background and their professions. The result of the meeting is Peace Papua Indicators. In addition, the meeting also produced a shortterm strategy refers to the process of lobbying to the Ministry and Government agencies in order to create a breakthrough on the issue of Papua at the end of the government of Susilo Bambang Yudhoyono.

Furthermore, the fourth explorative meeting held in January 2014 in Yogyakarta. Governor of DIY opened and supported this session and advised the Government of Indonesia to acknowledge that the issue of West Papua as a political issue. The opening of the office Organisasi Papua Merdeka (OPM) in the UK and the sympathy of the international non-governmental organizations is evidence 
of the problems in Papua. Governor of DIY encouraged the Indonesian Government to keep an open dialogue with Papuan people in 2014 and warned that dialogue could not happen if both sides remain in their views.

The fifth explorative meeting was held in September 2014 in Semarang opened by the Governor of Central Java. The event was attended by almost all participants in the meeting of Jakarta and Papua and local government officials. Governor supported this explorative meeting and stated that Papua is an integral part of Indonesia. The meeting is expected to be a new approach to building a stable and peaceful Papua through a dialogical approach towards reconciliation Papua. The meeting was attended about 41 participants from Jakarta and Papua, including representatives of the ministries and agencies to implement policies and programs in Papua following their respective responsibilities. This meeting resulted in a policy paper submitted directly to the President Joko Widodo in September 2014.

Based on the policy paper presented by the PPN, The President implemented some policies to increase the confidence of the people of Papua to the government, namely the liberation of political prisoners/detainees and providing access to foreign journalists to Papua. In May 2015, the President granted clemency to the five political prisoners in Papua. These five political prisoners were convicted of Arsenal burglary in Wamena in 2003. This effort is the first step to building Papua with the approach of peace and prosperity. Granting clemency can be interpreted as a policy reconciliation to realize Papua peace. In addition, the provision of the widest access for foreign journalists to Papua is evidence of press freedom prevail throughout Indonesia and in the absence of discrimination against Papuans. However, the reality of political institutions and security does not fully support this policy; for example, they only allow foreign journalists who are considered not discredit the Indonesian government.

In February 2015, the sixth explorative meeting held in Jakarta, attended by Coordinating Minister for Political, Legal and Security Affairs and the Minister of Women's Empowerment. The minister claimed to have a strategy of development in Papua and West Papua Provinces using welfare approach. The presence of two ministers in the explorative event showed a high appreciation at the PPN. It is magnificent at building trust Papuan representative because they believe that this forum can become a place for their aspirations. Furthermore, the seventh explorative meeting in November 2015 in Bogor, to discuss the urgency of the cessation of violence in Papua and the internationalization of Papua issues. The meeting discussed the root causes of the political, legal, security and human rights (HAM) in Papua. Another topic discussed is the anticipation of political violence following local elections simultaneously on December 9, 2015. Based on the series of explorative meeting, it can be found out that continuously informal communication between national government officials and Papuan leaders is necessary to reduce the gap of understanding related to causes and problems of Papuan conflict. At least, the meeting can be a space for connecting the conflicting ideas and parties into table peacefully.

\section{Methods}

This article is based on my study on peace campaigns conducted by the Indonesia Institute of Sciences (Lembaga Ilmu Pengetahuan Indonesia, LIPI) and the Peace Papua Network (PPN, Jaringan Damai Papua, JDP) between 2013 and 2016. Their campaign consists of a series of explorative meeting, expert meeting, and media briefing in Jakarta. I then analyzed information from these activities by a set of literature reviews on the contemporary Papuan studies and archival research. Besides to confirm the collected information and analysis, some interviews are carried out in Jakarta. Finally, information collected from 
observations, previous studies, and interviews convergent into analytical arguments. The method of analysis of is following the case, i.e., the establishment of PPN and its peaceful campaigns both in Jakarta and Papua.

\section{Results and Discussion}

The Results of Explorative Meetings and Its Implications on Peace Building

Through a series of explorative meetings, PPN formulates eight problems faced by Papuan. These issues are: (i) vertical conflicts include stigma separatists, banning the use of symbols region, violence committed by Indonesian forces and armed groups, and conflicts of Indonesian nationalism versus ethnonationalism Papua, (ii) political violence in local elections, division and corruption, (iii) the inconsistency of government policy with its implementation especially its less attention to local values, (iv) the obstacles to the implementation of good governance, (v) the policy on state security but not on human security, (vi) disharmony implementation of modern and traditional economy as well as the rights of indigenous peoples to the natural resources that are not protected, (vii) limited and uneven qualified teaching staff and infrastructure of education, and the school curriculum that have not accommodated the cultural values of Papua, (viii) limited and not the prevalence of qualified health personnel, limited health infrastructure quality, less nutrition community programs, high mortality rate of pregnant women and children, and high levels of Human Immunodeficiency Virus (HIV) (TKP LIPI \& JDP, 2015, p. 3-4).

Explorative meeting participants from Papua more respond to the problem of stigmatization separatism, the use of symbols of Papuan culture, and violence in Puncak Jaya where a number of Indonesian armed forces and Free Papua Organization involved in armed conflict. Another topic is the number of policies and regulations for
Papua, but the people of Papua sees just a little bit of policies and regulations that have been implemented, while some of them are failed to be implemented such as Act No. 1/2001 on the Papua Special Autonomy. On that occasion, the Government said that they have committed to provide a solution to the problem of political conflicts, security, socioeconomic and other development aspects, although the government also has obstacles in the coordination and implementation of the program. The Government also emphasized that they will discuss with various interest groups in Papua, including Organisasi Papua Merdeka (OPM).

Security problems, law, and politics became sensitive issues at the explorative meeting. Some questions that need to be answers related to the safety aspects, law, politics, not just the problem of development in Papua. There are still different points of view on the root of the problem, and the problem in Papua is based on a certain reality, namely nationalism Indonesian and Papuan nationalism. Also, there are different perceptions between restrictions on access to Papua by the lack of access to Papua, especially for foreign journalists.

Socioeconomic problems in Papua are getting a lot of attention from the participants in the dialogue. Such as the need to improve coordination and synergies; enhance the quality of the management of natural resources; community empowerment; Papua resource management by involving local government, communities, and enterprises; and build infrastructure, especially for education and health services. In the sector of teaching services, it is recommended to create a specialized curriculum in Papua taking into remote areas considering the inability of some ethnic groups to talk with Indonesian and education levels are low compared to other provinces. Another recommendation is to open a boarding school related to the difficulty of access to some 
areas, boarding schools for certain ethnic groups. Those in the health care sector are recommended to do the following: improving health care and to combine traditional and modern health care to remote communities in Papua. Those in the economic sector are supported for greater recognition of the land and ownership rights.

Social and cultural problems in Papua which also discussed in the explorative meeting primarily about problems of education in Papua and the need to view culture as a totality and Papua determinant factor in governance and social life in Papua. Another issue is the need to use local languages/dialects as part of the curriculum. Another thing discussed included customary land and customary rights over customary land mapping and organizing and setting back the Papua Adat Council (Dewan Adat Papua, DAP) (LIPI and JDP, 2015). ${ }^{6}$ This topic has been widely discussed in academic discourse, for example, Martanto (2007: 183-184) says that the exploitation of natural resources in Papua land affected on the sustainability of Papuan tribes because their everyday life depends on nature.

One implication of explorative meetings is that the idea of dialogue become wider discussed among both national government officials and Papuan people. Some moderate national government officials begin to understand that the dialogue is necessary to resolve social and economic issues. Event President Jokowi said that he is willing to dialogue with Papuan people including those who want to free Papua. However, the national government has no a comprehensive road map of peaceful dialogue. On the other side, some leaders of Papuan church and tribal organizations also support the idea of dialogue to end political violence in Papua land.

Nevertheless, the results of explorative

6 The summary of explorative meetings results, "an effort to achieve consensus for peace in Papua." meetings are limited to discourse on a personal level, namely the government officials as well as leaders of Papua. Government delegations in the explorative meeting, in reality, do not have authority when they return to their institutions. It is due to the strong ideology of chauvinistnationalism among national government officials that legacy of the authoritarian New Order regime. The political situation in Papua showed that the escalation of political violence committed by the military and police against the Papuans still occurs. Increasing violence in Papua reduces the government's commitment to the peaceful settlement of Papua. This violence is ranging from kidnappings, shootings, arrests, killings by state officials or by civilians in various regions of Papua and West Papua.

Although the Indonesian government has allocated IDR 203.5 trillion to Papua between 2002 and 2015, the Papua issue is yet to be resolved. ${ }^{7}$ ELSAM (2015: 29) noted some political violence committed by Indonesian security forces in Papua and West Papua province in 2012 and 2013. During 2012, there have been 139 acts of violence perpetrated by security forces against indigenous Papuans. As a result, 40 civilians died, and 155 people were injured, three military members were assassinated, ten people were injured, and three armed civilians were killed, and two people were injured. Acts of violence in 2013 it increased to 151 events are accompanied by an increase in the number of victims. In that year, as result of political violence, 106 civilians died, and 220 people were injured, one police officer was killed, and ten police officers were injured, 13 military members were assassinated were killed and five people injured, and five armed civilians killed. The International Coalition of

\footnotetext{
This is all funds including special autonomy, infrastructure and other transfer from the national government to both Papua and West Papua province. Presented by a speaker from government in an explorative meeting with the media in Jakarta on May 11, 2016.
} 
West Papua (ICP, 2017: 9) reports that there are 76 cases of torture and 8 cases of extra-judicial killing in 2014. The number of torture cases reduces into 19 but the number extrajudicial killing cases increased into 10 in 2015.

Another problem is the increasingly smaller space for Papuan political expression. Freedom of speech is guaranteed by the 1945 Indonesian constitution has been reduced by the police in Papua since 2012. It can be observed in the peaceful demonstrations conducted by the West Papua National Committee (KNPB) was dissolved, and its leaders have always filed by the court. The demand for the right of self-determination by KNPB should not be taken with the legal and security approach but should be responded with a dialogical approach. Increasing security crackdown on demonstrations KNPB, the growing campaign for independence abroad carried out by diaspora political movement in Papua. In fact, the security forces had done to overreact when they arrested the Catholic priest during a demonstration for demanding the resolution of Paniai case. The escalation of violence and restriction of freedom expression in Papua land tend to lead the internationalization of Papuan issues.

In December 2014, all Papuan liberation organizations, namely the West Papua National Coalition Liberation (WPNCL), National Parliament of West Papua (NPWP), West Papua Federal Republic State, United in Vanuatu under the United Liberation Movement for West Papua (ULMWP). In June 2015, the ULMWP was accepted as an observer in Melanesian Spearhead Group, a cooperative organization of Melanesian states in the Pacific. However, the Indonesian government also established Melanesia-Indonesia (Melindo), which is represented by five provinces (Papua, West Papua, Maluku, North Maluku and East Nusa Tenggara), which was also included in MSG as an associate member. The ULMWP is more popular than Melindo in Papua, getting a stronghold in all regencies and cities in the whole Papua land. The works of PPN, therefore, are still needed to consolidate Papuans and to prepare the dialogue between Papuans and the Indonesian government. In such a dialogue, Papuan people may be represented by the ULMWP (Pamungkas, 2016: 3-5).

\section{Conclusion}

Based on the descriptions above, it is concluded that PPN has actively and intensively campaigned for Papua Peace Land. The campaign was conducted via a series of public consultations with Papuan and migrant living in Papua, the 2011 Papua Peace Conference, and some explorative meetings between Indonesian government officials and Papuan leaders. As a result, the idea of opening a national dialogue has been widely accepted in both Papuan and migrant living in Papua. The Indonesian government has also recognized the idea of dialogue in the context of national integration.

The idea of dialogue to settle the Papuan conflict received a positive response from both parties due to they belief that "dialogue will not kill anyone." However, it was also acknowledged that the people who died during the conflicted times were not able to attend the dialogue. Dialogue is one condition for reconciliation and peace in Papua land. In the future, the talks concerning the PapuaIndonesia integration should be conducted in peaceable ways. The security approach is no longer acceptable by international communities. This approach, therefore, will not contribute to the peace building and maintaining national integration, but vice versa shall make Papuan people away from Indonesia.

This study demonstrates that the continuous informal communication between conflicted parties is necessary to increase mutual trust, but not enough without a formal dialogue for reconciliation. Several explorative meetings between national government officers and Papuan leaders do not manifest in a 
dialogue for reconciliation between the national government and Papuan resistance's movement represented by the United Liberation Movement for West Papua (ULMWP). Consequently, political violence and marginalization against Papuan continue in line with the exploitation of natural resources. Here, without dialogue, positive peace in Papua land is hard to be realized.

\section{References}

Anderson, B. (2015). Papua's insecurity: State failure in the Indonesian periphery. Honolulu, Hawaii: East-West Center.

Bhakti, I. N., Yanuarti, S., \& Nurhasim, M. (January, 2009). Military politics, ethnicity, and conflict in Indonesia. (January, pp. 1-34, CRISE Working Paper No. 62).

Braithwaite, J., Braithwaite, V., Cookson, M., \& Dunn, L. (2010). Anomie and violence: non-truth and reconciliation in Indonesian peacebuilding. Canberra: Australian National University.

Chauvel, R. (n.d.). Constructing Papuan nationalism: history, ethnicity, and adaptation. Retrieved from https://www.eastwestcenter. org/fileadmin/stored/pdfs/PS014.pdf

Drooglever, P. (2010). An act of free choice: decolonization, and the right to selfdetermination, London: One World Publication.

Elisabeth, A., Tebay, N., Sumule, A., Sudrajad, Pamungkas, C., Siregar, L.A. \& Manufandu, S. (2015). Bersama-sama Membangun Papua Damai. Policy Brief. Jakarta: LIPI \& JDP. Retrieved from http://jdp-dialog.org/ download/doc_download/63-policy-brieftim-kajian-papua-lipi-jdp

Elisabeth, A., Widjojo, M. S., Kurniawan, R., C., \& Blegur, S. (2004). Pemetaan peran dan kepentingan para aktor dalam konflik Papua. Jakarta: LIPI Press.

Elisabeth, A., Widjojo, M.S., Pamungkas, C., Al Rahab, A.E., (2005). Agenda dan potensi damai di Papua. Jakarta: LIPI Press.

ELSAM. (2015). Ancaman berkelanjutan, penyelesaian stagnan, laporan situasi hak asasi manusia di Indonesia 2013. Jakarta: ELSAM.

Galtung, J. (1969). Violence, peace, and peace research. Journal of Peace Research, 6(3), 167-191.

Heidbuchel, E. (2007). The West Papua conflict in Indonesia: Actor, issues, and approaches. Wettenberg: Johannes Hermann J \& J Verlag. Hernawan, Y. B., \& Braithwaite, J. From the theatre of torture to the theatre of peace: The politics of torture and re-imagining peacebuilding in Papua, Indonesia (Unpublished doctoral dissertation). Australian National University.

ICG. (2012). Indonesia: dinamika kekerasan di Papua. Brussels: International Crisis Group.

International Crisis Group (ICG). (2010). Radikalisasi dan dialog di Papua. Brussels: International Crisis Group.

International Coalition of Papua (ICP). (2017). Human rights in West Papua 2017. Wuppertal, Germany: ICP.

King, P., Elmslie, J., \& Webb-Gannon, C. (2011). Comprehending West Papua. Sydney: Centre for Peace and Conflict Studies, University of Sydney.

Kirksey, E. (2012). Freedom in entangled worlds: West Papua and the architecture of global power. Durham and London: Duke University Press. Kivimaki, T. \& Thorning, R. (2002). Democratization and regional power sharing in Papua/Irian Jaya: increased opportunities and decreased motivations for violence. Asian Survey, 42(4), 651-672.

Lundry, C. (2009). Separatism and state cohesion in Eastern Indonesia. (Unpublished doctoral dissertation). Arizona State University.

MacLeod, J. (2011). Pathways to dialogue in Papua: diplomacy, armed struggle or nonviolent resistance?. In Bartkowski, M. (Ed.). Rediscovering Nonviolent History: Civil Resistance Beneath Eulogized Violence. Colorado: Boulder, CO, Lynne Rienner Publihsers.

Martanto, U. (2007). Perubahan lingkungan dan konflik kekerasan membaca Papua melalui pendekatan environmental security. Jurnal 
Ilmu Sosial dan Ilmu Politik, 11(2), 173-192.

McGibbon, R. (n.d.). Pitfalls of Papua: Understanding the conflict and its place in Australia-Indonesia relations. Retrieved from https://www.lowyinstitute.org/sites/ default/files/pubfiles/McGibbon,_Pitfalls_ of_Papua_1.pdf

Pamungkas, C. (2017). Internasionalisasi Konflik Papua: Menyelusuri Perjalanan ULMWP dan Diaspora Papua. In C. Pamungkas \& S. R. Rusdiyarti (Eds.), Updating Papua Road Map (pp. 171). Jakarta, Indonesia: Yayasan Pustaka Obor Indonesia \& Tim Kajian Papua - Lembaga Ilmu Pengetahuan Indonesia.

Penyelesaian Papua dengan Pendekatan Pembangunan. (2017). Suara Pembaruan, November 10. http://sp.beritasatu.com/ pages/e-paper/2017/11/10/files/assets/basichtml/page-3.html\#

Rutherford, D. (2012). Laughing at Leviathan: Sovereignty and audience in West Papua. Chicago, IL: University of Chicago Press.

Santoso, P. (2012). Ber-NKRI Secara Lebih Baik: Telaah Etis Percepatan Pembangunan Papua. Retrieved from http://www. academia.edu/1098076/Ber-NKRI_Secara_ Lebih_Baik_-_Prasyarat_Percepatan_ Pembangunan_Papua

Supriyono, J. (2014). Diskursus kolonialistik dalam pembangunan Papua. Jurnal Ultima Humaniora, 1, 59-78.

Suryawan, I. N. (2011).'Komin Tipu Komin: Elit
Lokal dalam Dinamika Otonomi Khusus dan Pemekaran Daerah di Papua. Jurnal Ilmu Sosial dan Ilmu Politik, 15(2), 140-153.

Tebay, N. (2009). Dialog Jakarta-Papua: sebuah perspektifPapua. Jayapura:SekretariatKeadilan \& Perdamaian, Keuskupan Jayapura.

Tim Kajian Papua LIPI \& Jaringan Damai Papua. (2015). [Notulensi Pertemuan Eksploratif Ketujuh di Bogor]. Unpublished raw data.

Viartasiwi, N. (2014). Autonomy and Decentralization as Remedies?: Counterinsurgency Tactics for the West Papua Conflict in Democratic Indonesia. 立命館国際 研究, 27(1), 283-304.

Wassel, T. (2014). Timor-Leste: Links between peacebuilding, conflict prevention and durable solutions to displacement. Washington D.C.: Brookings Institution.

Widjojo, M. S.\& Tebay, N. (2010). Indikator Papua Tanah Damai versi Masyarakat Papua. Jayapura: Jaringan Damai Papua.

Wilson. (2017). Transformasi gerakan kaum muda Papua In C. Pamungkas \& S. R. Rusdiyarti (Eds.), Updating Papua Road Map. Jakarta, Indonesia: Yayasan Pustaka Obor Indonesia \& Tim Kajian Papua - Lembaga Ilmu Pengetahuan Indonesia.

Wiratri, A. (2017). Peran LIPI dalam Proses Perdamaian Papua. In C. Pamungkas \& S. R. Rusdiyarti (Eds.), Updating Papua Road Map. Jakarta, Indonesia: Yayasan Pustaka Obor Indonesia \& Tim Kajian Papua - Lembaga Ilmu Pengetahuan Indonesia. 